\title{
PRESS PERFORMANCE AMID THREATS OF TERROR. EXPLORING REPORTING THRESHOLDS AND CRITICISM IN ELITE COVERAGE OF AN IDENTITY CARDS BILL.
}

\author{
Julian Matthews - School of Media, Communication and Sociology, University of \\ Leicester
}

Sarah Cameron - University of Leicester

Authors' final version of:

2018. Press Performance Amid Threats of Terror. Exploring Reporting Thresholds and Criticism in Elite Coverage of an Identity Cards Bill. Journalism Theory, Practice and Criticism. (December 7, 2018. doi.10.1177/1464884918816243).

\begin{abstract}
It is now commonplace to suggest that acts of terrorism on home soil impact on the media's ability to challenge the anti-terror policies that follow immediately from them. Still, complex contexts can emerge, and this paper focuses on one that shapes a media response to a proposed UK anti-terror policy in 2006. It observes how proposed legislation for an identity card scheme, following closely after the 2005 London bombings, is reported in the elite press according to different 'thresholds'. Emerging from an initial (i) observing of political conflict and a (ii) detailing of claims made about the policy are (iii) moments of performed criticism of the policy as a 'threat' to the British public's 'civil liberties' by these newspapers. This verbally 'empowered' coverage provides an important exception to the previously observed media passivity in response to anti-terror policies / propaganda. Further, the paper argues that this is instigated by a complex context of political contest and reproduced cultural associations that encourage the performance of these newspapers' 'fourth estate' role.
\end{abstract}

Key words: Elite media, press performance, Identity Cards Bill/ Act, reporting thresholds, cultural values, political contest 


\section{Introduction}

In February 2006, the UK government presented an Identity Cards Bill to parliament as a prepared governmental response to then recent acts of terrorism in Europe (Madrid -11.3.2004, and London - 7.7.2005). This paper explores the elite reporting of the Identity Cards Bill to assess the impact of these conditions on the media's performance. Often, studies introduce the influence of government commentary operating on the general reporting of anti-terror legislation at these times. It is claimed that the media respond positively and uncritically to the policy suggestions that are communicated to them via government communication strategies (Miller and Sabir 2012; Zelizer and Allan 2002). Such actions reflect the context of heightened threats of repeat terror attacks and the governments' recently agreed stance of a 'war on terror' (see Freedman and Thussu 2012). In the months following the London bombing attacks (in 2005), the UK government proposed to restrict some of the civil liberties of the UK population in the name of safeguarding them against imminent future terrorist attacks. This proposed UK legislation, despite appearing to follow the authoritarian policy response already implemented and largely unchallenged in the USA, produced political discussion and disagreement in both Parliamentary Houses later in 2006. As we will hear, analysing these circumstances helps to uncover a complex context and one that influences reporting in ways that are not acknowledged in work on terrorism, to date.

This paper examines the importance of this context to subsequent media actions in this case. The identity or 'entitlement' card, first discussed in the UK parliament in 1995, was proposed as pre-emptive government legalisation following the observed 9/11 (2001) attacks in the US. Later in 2004, the Labour government introduced this scheme and emphasised it as part of their re-election manifesto (in 2005). The London bombings (2005) intensified these discussions and the Identity Cards Bill was first read in House of Commons in December 2005. This paper picks up on what follows. It traces the reporting of the Identity Cards Bill in four elite UK newspapers over a three-month period (February-April 2006). The recognised political focus and space these newspapers offer to voices and debate provide here perfect examples to assess media autonomy in context of heightened government claims making about terrorist threats. Analysing reported themes and voices and the contexts in which they emerge will uncover whether these newspapers engage critically with the issue. 


\section{Media performance in times of crisis}

Studies agree that the context in which the media operate often shapes media actions. Circumstances that form at times of crisis, in particular (such as imminent or recurrent threats of terrorist attacks), inform uncritical reporting, it is often suggested (Altheide 2006). Acts of actual or potential terrorism perpetrated on 'home soil', as an example of a time when societies face heightened threats, instigate a change in the journalism produced and one that deviates from its normal 'critical' reporting practices (Zeilzer and Allan 2002; Schudson 2002). These altered reporting practices provide opportunities for political and social elites to enter the news stage to voice condemnation of terrorists (McChesney 2002; Montgomery 2005) and to outline a largely unchallenged response to such actions (Lewis and Reese 2009). Often explained at such times is a need for policy change to prevent future acts of terrorism (see Chermak 2003), such as the proposed implementation of identity cards in the UK that features as the subject of this paper. In responding to these scenarios, the media perform, it is often argued, a subordinate role that defines events and justifies actions according to homogenised political elite commentary (Herman and Chomsky 1988).

Nonetheless, it is important to acknowledge here that there are circumstances that can counteract these restricted actions. Reporting of some sustained conflicts do offer coverage that is 'differentiated, unpredictable and politically contingent' (Cottle 2006: 412) including that focused on terrorism. Media actions emerge then out of developing contexts. Situations arise in the process of covering a (political) conflict that provide journalists with autonomy to comment critically on the claims and actions of elites (Barnett and Reynolds 2009) and, therein, to move closer to fulfilling a professional obligation to their readers as citizens (Althaus, 2003). Instances exist where the media uncover notable misjudgements of, and wrongdoing among, elites during conflicts (Thompson 2000; Kampfner 2003) for instance. Apart from reporting instances of misconduct, the media can perform sustained criticism of government actions and policy (such as an identity cards scheme) in response to catalysts found external to its news making environments (Corera 2004). An observable political contest over an issue can 'activate' forms of journalistic engagement and ultimately critical reporting (Entman 2003), for example. From observing these activities in political institutions, journalism will often index disagreements among political elites (Bennett 2011) and in the process offer forms of comments, voices and coverage that are markedly different from those in reporting that is influenced by government propaganda (see Corner 2007). This leads at times to an observed 
interplay between the views of elite and those of non-elite actors and toward unexpected outcomes (Cottle 2004: 188).

Elsewhere, the context that surrounds a conflict, including that of war, can allow for the reproduction across media coverage of 'different currents of opinion and forces at play' (Tumber and Palmer 2004: 94). A pertinent example of straightforward anti-war and antigovernment sentiment occurred in the reporting that followed an outcry of UK public opinion in the lead up to the war in Iraq (Freedman 2003), for instance. In these instances, as Wolfsfeld (1997) describes, journalists bring together new information and pre-existing frameworks of meaning in a process structured by 'the professional and political culture' of their news mediums (p54). On this basis, journalists reproduce either 'shallow' or event-based stories or those with more 'depth' (ibid). The absence of political elite commentary on a developing issue offers opportunities for the media to devise deep or autonomous commentaries, for example. On these occasions, journalists take the discursive initiative to question the official versions of events in the absence of elite commentary (Murphy 1991; Critcher 2002).

In addition, collective perceptions of the legitimacy of an issue accrue among news teams over time and these understandings can encourage critical reporting. At play in these judgements are common understandings or 'schemas' that are shared by political actors and publics within a political culture (Entman 2004). Newsrooms will often challenge the legitimacy of elite positions and the policies that follow from them when they observe elites to re-rehearse an already discredited position or to provide misleading information (Reilly and Miller 1997; Cooke et al 2006) or when their accounts appear as simply ambiguous (Entman 2003). While news teams devise critical reporting on the basis of their knowledge of issue developments, or according to their previous framing of an issue over time, they also report issues according to the presence of 'symbolic resonances'. Values such as 'freedom' and 'progress' are encoded in some issues and these values shape their subsequent reporting (this aspect will be discussed in the case of the identity cards issue, later). Often these 'cultural assumptions' emerge as part of the political centre's (i.e. government's) framing of issues, and, in the process, these stimulate the reactions of other significant political elites and journalists (Entman 2004). When reporting reflects this interplay, it can become potentially 'transformative' (see Cottle 2004). Certainly, their presence or absence in government communications provide opportunities for journalists and other elite political actors to confer and to perform criticism of government positions or policies (Wolfsfeld 2011). Sometimes, as Hallin (1986) suggests, it is the changing 
environment (or spheres) in which journalists inhabit at these times that dictates whether their reporting reflects consensus values (sphere of consensus), conflicting elite opinion (sphere of legitimate controversy) or moves to be more adversarial in outlining deviant perspectives (sphere of deviance).

Thus, in addition to the recognised constraints on media actions, there are several potential contexts that can work to stimulate critical media performances. Knowledge of these will help to direct the following analysis of the reporting of the Identity Cards Bill. Nevertheless, the above review explains that different and individual circumstances underpin individual critical press performances. The use of any of these individually could narrow then the scope of an analysis of the reporting of the Identity Cards Bill and potentially obscure the complexities that underpin this coverage. Consequently, this paper will be mindful of the potential and coexisting factors (i.e. political actions, contest and cultural definitions) that could be shaping stories and any movement between different story types over the course of this reporting. It will examine the continuous reporting of the issue to capture them and this effort will be guided by previous work that explores the phases and the progression of continuous reporting (see Cottle 2004 for a review). Less interested in charting a developing (social) drama however, it will explore the 'reporting thresholds' that shape coverage, and view each reporting threshold as marking the beginning and the end of a context that underpins an aspect of the selected coverage. In sum, the analysis of the reporting of the Identity Cards Bill will respond to the following questions:

-What observable contexts (i.e. reporting thresholds) mark the elite press reporting of the Identity Cards Bill?

-What functions do the factors common to these contexts (i.e. the thresholds) play in encouraging the performance of a critical press voice?

\section{Studying press performance}

The research examined the presence of 'reporting thresholds' and subsequent press performances in the continuous reporting of the Identity Cards Bill. The process of the Royal Assent of the Identity Cards Bill into the Identity Cards Act 2006 (February - April 2006) marked the time period in which to begin the selection of relevant news content. The research used this period to collect reporting from elite newspaper journalism, in contrast to lower 
market news outlets, as this provided an opportunity to study detailed elite reporting. In fact, the issue was observed to be largely absent from the agendas of media in the lower market positions at this time. Thereafter, articles were selecting using the terms 'Identity Cards / Identity Cards Bill' in the Lexis-nexus database. Following a process to remove duplicate articles, 97 news articles were selected for detailed analysis (12 in February; 45 in March and 40 in April 2006). The importance of the issue for the selected newspapers was reflected in the even spread of coverage between their weekly and weekend equivalents (Daily Telegraph - 18 the Times -22; the Independent - 27 the Guardian - 30).

The research analysed the story themes, story voices and the tone of stories to establish the different thresholds in the continuous reporting of the Bill. The concept of 'theme' was selected purposefully to map continuity and change in this coverage. Its use helps to uncover insights into the definitional process of these stories in a similar way to the use of frames. However, for this study, theme is viewed as a more flexible tool to capture the complexities in the relationship between context and reporting. In short, it does not reduce reporting to the influence of claims making or journalistic practice as is common in the use of 'frames' (see Vliegenthart and van Zoonen 2011). The analysis used the headline, the news content and the voices that appeared in each of the stories (see Tankard 1993) to identify the theme categories. This inductive process observed reporting that focused on: (i) concerns related to identity cards (e.g. compulsion, reform and civil liberties), (ii) the technology and the problems associated with the implementation of an identity cards scheme (e.g. technology, cost and legislation) and observations of political conflict, defined by their location in the political system (i.e. cross house conflict, cross party conflict, and internal governmental conflict). In addition to measuring issue themes, the research mapped how newspaper stories positioned themselves in relation to the issue (i.e. their stance). Adapted from other recognised studies (e.g. Tumber and Palmer 2003 - based on the tone expressed across a given story and as measured in terms of headline, main paragraph and voices), the process explored the positive ('pro'), neutral ('neutral') or negative ('anti') responses to the issue. This was then cross-tabulated with the timing of the reports to uncover the presence of, and change in, the tone of stories over time.

In addition, the research explored the voices that appeared across the selected stories alongside the story themes to help to establish the reporting thresholds that underpinned the performance of the newspapers. Descriptions of the individual voices were used to situate each voice within one of eleven groups of speakers, including spokespeople from: senior government, general 
government, senior opposition party, general opposition party, House of Lords / Peers, pressure group, academic / expert, private sector, public sector, member of public, other. After categorising these voices, the research sought to ascertain their verbal performances in the reporting. This process mapped whether sources were talked about in news stories (thus gaining coverage) or were given opportunities to speak (thus gaining access) - both of which provided insights into those voices that gained a discursive foothold (Ericson et al, 1989) in discussions of the Identity Cards Bill. Further, to grasp the presence of a critical media performance, the research examined the presence and the positions of recorded judgements offered by different voices on the Identity Cards Bill in the reporting thresholds. Finally, to ensure reliability in the coding and analysis of the newspapers, two coders in addition to one of the authors coded a random sample of 7 articles. This pilot study revealed that there was agreement over the definitions of the research categories and their subsequent selection.

\section{Observing a collective performance}

The research finds that the selected newspapers reproduce similar story themes, story tone and story voices over the sample period in 2006. Important to their reporting is the political context that develops around the identity cards issue. In contrast to theoretical assumptions about the dominance of government communication on the reporting of terrorist related matters, this coverage does not appear to passively accept or to reproduce the UK government's championing of their new Identity Cards Bill. Rather, as we will observe, the newspapers' reporting shares similarities. These similarities demand that we cast aside, in addition to the views of government dominance, those of the influence of newspapers' different political perspectives and market positions that generally determine their (different) reactions to issues.

The reporting shows that two types of news story underpin this continuous coverage (See Figure.1). Stories that focus on the ongoing political conflicts over the Identity Card Bill are particularly prominent. These detail the geography of the political conflicts over the issue, including how the main positions and the challenges to them emerge 'cross-house' (between the House of Commons and the House of Lords $-\mathrm{n}=10$ ) as is illustrated by the story 'Peers stand firm against ID cards' (Independent 16 March). Conflict emerges also 'cross party' (between political parties $-\mathrm{n}=4$ ) as the Times shows with the story 'The Conservatives are refusing to back both the introduction of ID cards and the glorification of terror legislation....' 
(10 February). Finally, conflict is observed as internal to government $(n=2)$ such is demonstrated in the story 'Blair must give further ground' (Independent $8^{\text {th }}$ February).

The claims made about the Identity Card Bill form an additional story type and one that dominates the developing coverage. Discussion of the potential impact of the implementation of an identity cards scheme on the 'civil liberties' of the British people provides a prominent theme $(\mathrm{n}=35)$ that is reproduced. On the $19^{\text {th }}$ February, an Independent article features claims that the scheme represents 'creeping covert compulsion' and a country that is 'sleepwalking towards the surveillance state', for example. A concern about the compulsion of people to have / to use / to carry identity cards, appears in those stories following closely behind ('compulsion theme'; $n=15$, e.g. ' 10 reasons to oppose ID card scheme', Independent 13 February). Themes that emerge in lesser overall numbers discuss problems with the practicalities of an identity card scheme such as that of cost $(n=11$, e.g. 'ID cards have cost $£ 32 \mathrm{~m}$ so far', Times 23 February), technology (n=9, e.g. 'Dutch firm exposes flaw in security of ID cards', Times 3 February) alongside those on political reform (n=6, e.g. 'Hoon: ban Lords from challenging controversial Bills' - Independent 5 March).

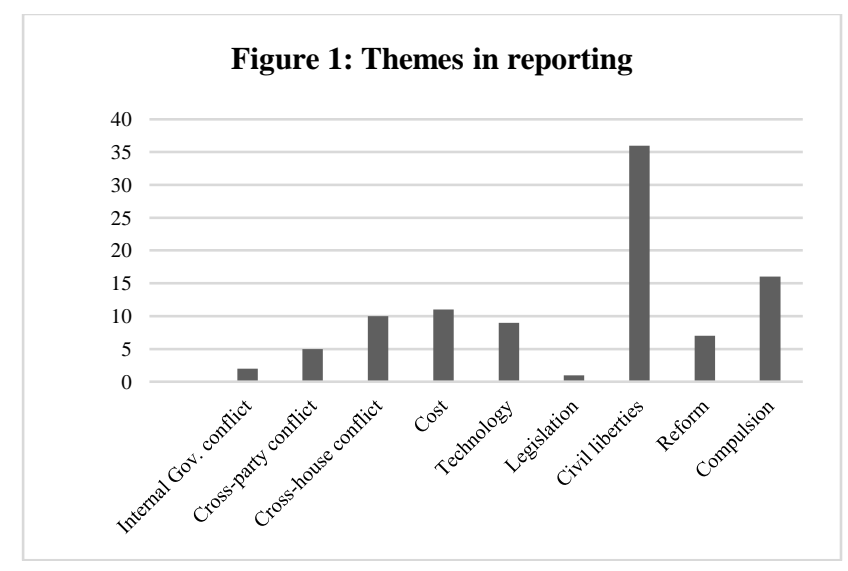

Further, the newspapers' reporting of these claims about the impact of identity cards and their practicalities remain relatively constant across the period of the reading of the Bill and those discussions within, and conflicts with, the House of Lords that lead later to an agreement to pass it (29 March). Observed together, the reproduced themes appear in even numbers before the coverage reveals a raise in the reporting of conflict between the parliamentary houses ('cross-house conflict' theme). Moreover, a significant presence of the civil liberties theme 
can be witnessed in April (for example, 'The battle for civil liberties' in the Independent, 24 April), despite an observed end to the politicized conflict and an emerging political agreement between the parliamentary houses over the Bill at this time (late March 2006).

The stance of reporting is another feature of the collective coverage that is observed to change over the sample period. Looking closely at the presence of 'stance' in the stories, we observe an indifferent / neutral stance toward the Identity Cards Bill is present during the initial process of political conflict $(n=47)$. Produced according to traditional journalistic practice, the configured stories offer observational reporting of the episodes of conflict taking place within The House of Commons. Comments focus mainly on the actions of the Prime Minister in either returning to vote for the ID cards Bill (Independent 7 February), to confront rebel MPs (Independent 8 February) or eventually to 'give ground' to critics of the Bill (Telegraph 10 February).

The stance in the reporting of the conflict over the Identity Cards Bill is maintained within coverage of The House of Lords (see Figure.2). These headlines chart the actions of MPs and Peers to fight over terrorism measures (Times, 17 March), to defeat the ID Cards Bill (Independent $21 \mathrm{March}$ ) and to, what is described as, play 'ping pong' among themselves with the legislation (Telegraph 17 March), Yet, as we will discuss later, observed changes in the political context influence the reproduction of an 'anti' stance and a transition to more critical and autonomous reporting in later months.

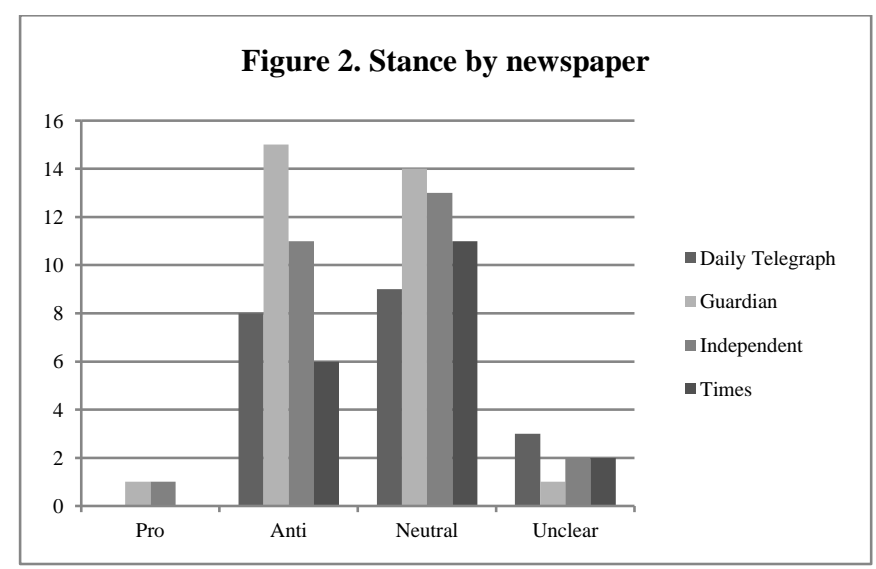

Figure.2, outlines the sustained discussion of the Identity Cards Bill. Included are reports that generally adopt either a neutral or a negative tone and collectively offer a limited space for 
government commentaries on the potential merits, and the successes, of the Bill. Still, writing in 'Ordinary people have the right to be protected' (Independent 24 April), Charles Clarke, the then Home secretary, outlines the governments' position on civil liberties and the criticisms prevalent in the media at this time. Elsewhere as the evidence shows, other stories reflect a developing negative ('anti') stance on the Identity Cards Bill $(n=40)$ and include critical claims making.

Moreover, the voices reproduced in these stories illustrate the character of this common coverage (see Figure .3). On the one hand, the presence of voices reveals the places where conflict originates, as we have heard. Government and opposition spokespeople and those peers from the House of Lords appear in significant number and these reflect the intra-party, cross party and cross house focus of the conflicts. On the other, they indicate developments in the coverage, particularly its changing stance on the identity card issue. For example, Shami Chakrabarti, Director of Liberty, the civil liberties watchdog, features in February to explain that 'Support for identity cards continues to wane in the country' and that what she sees as a doomed policy (or 'new Labour's poll tax') 'may be beaten yet'. (Guardian 14 February). Pressure groups (Liberty specifically is reflected above), academics and others from the private sector appear then as part of the ongoing evaluation of the Bill and of the viability of an identity card scheme in the UK that lies at its centre

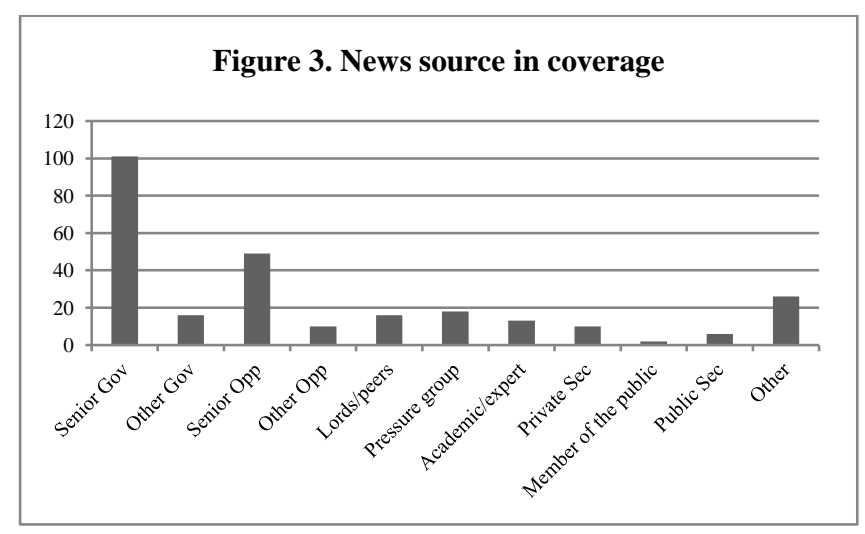

Thus far, this discussion has provided a brief overview of the features common to the newspaper reporting. Although similar to those that shape reporting of crisis events and scandals generally (see Canel and Sanders 2006), their presence here reflects a developing political context that is different to the political consensus that underpins coverage of general 
crisis or political wrongdoing. Elite press journalists operate to witness and, in turn, to react to the changes in this context at this time. Several thresholds emerge to characterise this reporting and their modes are discernible according to: (i) observed conflict, (ii) sustained criticism or (iii) press criticism (see Figure 4 for an overview). In short, this reporting serves to witness the political conflict over the Identity Cards Bill in addition to providing space for the various political criticisms levelled at the proposed scheme and its impacts. Moreover, these developments allow newspapers to perform their criticisms in final threshold, as we will see.

From establishing there is uniform coverage across the newspapers, we can move to analyse the contexts that shape it. Grasping the changing political context to the identity cards issue will provide therefore a backdrop to understand which political activities are being reported. Focusing on the claims making that builds around the issue in addition will reveal newspapers recognition of, and adherence to it and further its cumulative effect on the legitimacy of the Bill and any press performance that follows.

\begin{tabular}{|c|c|c|c|c|c|}
\hline \multicolumn{6}{|c|}{ Figure 4. Reporting Thresholds and the Identity Card Bill } \\
\hline Thresholds & Politicization & Reporting & Theme & Stance & Voices \\
\hline $\begin{array}{l}\text { Observed } \\
\text { conflict } \\
\text { (February) }\end{array}$ & $\begin{array}{l}\text { Introduction and legitimate } \\
\text { probing of the policy / Bill } \\
\text { Political discussion within } \\
\text { government and between } \\
\text { political parties in the House } \\
\text { of Commons }\end{array}$ & $\begin{array}{l}\text { Reporting of the policy process, } \\
\text { House of Commons based } \\
\text { political conflict and selected } \\
\text { criticisms of the policy /Bill }\end{array}$ & $\begin{array}{l}\text { Cross party } \\
\text { conflict } \\
\text { Cost } \\
\text { Civil liberties }\end{array}$ & Neutral & $\begin{array}{l}\text { Senior } \\
\text { government and } \\
\text { opposition } \\
\text { political party } \\
\text { figures } \\
\text { Limited } \\
\text { alternative voices }\end{array}$ \\
\hline $\begin{array}{l}\text { Sustained } \\
\text { criticism } \\
\text { (March) }\end{array}$ & $\begin{array}{l}\text { Conflict between Houses of } \\
\text { Westminster (Commons and } \\
\text { Lords) } \\
\text { Sustained political challenge } \\
\text { to policy/ Bill } \\
\text { Amendments to the Bill }\end{array}$ & $\begin{array}{l}\text { Reporting of prolonged conflict } \\
\text { before later agreement, between } \\
\text { Peers (House of Lords) and the } \\
\text { government } \\
\text { Sustained criticism of the Bill }\end{array}$ & $\begin{array}{l}\text { Cross house } \\
\text { conflict } \\
\text { Technology } \\
\text { Civil liberties }\end{array}$ & $\begin{array}{l}\text { Neutral / } \\
\text { negative }\end{array}$ & $\begin{array}{l}\text { Peers (House of } \\
\text { Lords) and } \\
\text { government } \\
\text { voices } \\
\text { Interest group and } \\
\text { experts }\end{array}$ \\
\hline $\begin{array}{l}\text { Press criticism } \\
\text { (April) }\end{array}$ & $\begin{array}{l}\text { Reaction to the government } \\
\text { policy, following agreement } \\
\text { over Bill }\end{array}$ & $\begin{array}{l}\text { The performance of press } \\
\text { criticisms of the policy / Bill }\end{array}$ & $\begin{array}{l}\text { Civil liberties } \\
\text { Compulsion } \\
\text { Reform }\end{array}$ & Negative & Press and critics \\
\hline
\end{tabular}




\section{Threshold 1: 'Observing conflict'}

Reporting in the first threshold commences in February (2006) and reflects the politicization of the issue at the time. In parliamentary circles, the government's Identity Card Bill is being discussed between the political parties in the House of Commons before it moves to be ratified in the second parliamentary house - the House of Lords. Critical exchanges between the political parties over the identity cards issue emerge and feature within the formalised process to ratify this legislation (i.e. the Identity Cards Bill).

Journalists experience of, and thoughts on, the developing context to the identity card issue are reflected in the dominant themes of their reporting. Figure.1, charts their responses to an emerging conflict over the proposed legislation, including reporting that follows the traditional reporting practice of 'impartiality' and 'balance'. This focuses on the intensity and the geography of the political conflicts before it offers more details on challenges made to the legitimacy of the policy of an identity cards scheme. As has been noted, reporting concentrates on the geography of the political conflict in Westminster, including those instances of (i) internal governmental conflict over the policy. The threshold includes claims from the Home Office about the importance of ID cards at the beginning of February. What follows charts The Prime Minsters return to the UK to vote on the Bill and then a showdown between the Prime Minister and party 'rebels'. Coverage recounts the PM's view that 'rebels beggar belief' and includes his call for loyalty from them and from other parties' MPs in the vote (Times 14 February). Subsequently, newspapers chart the government's narrow victory in the vote (Telegraph 14 February) and its change of opinion on ensuring identity cards are compulsory (Independent February 10), before the subject of cross party and political party conflict over the issue is replaced by (iii) cross-(parliamentary) house conflict over the issue. What follows charts the 'stand-off over ID cards and 'glorifying terrorism' (Telegraph 17 February) and the Bills defeat in the Lords (Guardian 1 March).

The stance adopted within the early reporting is another marked feature of this threshold. The newspaper journalists report the issue from an observational (neutral) stance. Headlines follow the actions or reactions of government, such as 'Clarke backs down over plan to make ID cards compulsory' (Independent 10 February). In addition to observing the conflicts between parties and parliamentary houses, newspaper commentary resembles an impartial recounting of these conflicts and the positions that inform them. What emerges in this threshold discusses the 
legitimacy of a policy to implement identity cards as a response to recent terrorist attacks. For example, the Independent leads with views from the government such as 'Blair says ID cards will help fight new security threats' (Independent 10 February) and this is complemented by others arguing that 'Blair must give further ground over Bill' (February 8) reported elsewhere.

In a move to personalise the issue, the reporting echoes concerns over the possibilities of identity cards to change the lived experience of Britons. Introduced is an unease over the (i) impact of the identity cards scheme (compulsion, reform and civil liberties) and over (ii) issues with the implementation of identity cards in the UK (legislation, technology and cost). Among these, two concerns stand above the others in terms of their overall number. The prevalent concerns of the 'cost' of an identity cards scheme and the potential impact of such a scheme on 'civil liberties' appear most often here. Claims about 'cost' assess the cost effectiveness of the proposed ID cards scheme ('ID cards cost 32 million so far reports the Times, 25 February). Further, isolated claims about the Bill as a potential 'gallop to serfdom' (Times 16 February) and as 'compulsion by the back door' (Independent 21 February) mark the headlines of stories on civil liberties. Still, the detached mode of reporting allows for the reproduction of the voice of government and others to make claims and to respond to them within these stories.

Up to this point, we can observe the traditional actions of elite newspapers to reproduce newsworthy stories on political conflict and the political claims making associated with them. What follows in the politicization of the Identity Cards Bill in threshold two, helps to explain how the coverage positions itself in response to a sustained up-swell of critical claims making about identity cards and the proposed identity cards scheme.

\section{Threshold 2: Marking 'sustained criticism'}

The actions integral to the ongoing politicization of identity cards in March 2006 offer an important context that marks the second reporting threshold. Before the start of this month, the Identity Cards Bill had already passed through the second parliamentary house - the House of Lords. As part of an effort among its peers to quash the legislation, the house recommended 279 amendments to the evolving Bill in February 2006. Some of these were overturned and some were amended. Between returning to the House of Lords on the $6^{\text {th }}$ March, the Bill moves between the Houses of Westminster. In the process, it is overturned twice $\left(13^{\text {th }}\right.$ and $20^{\text {th }}$ in the Lords) and agreed three times $\left(13^{\text {th }}, 16^{\text {th }}, 21^{\text {st }}\right.$ in the commons) before gaining a final agreement 
in the Lords on 29 $9^{\text {th }}$. The Bill gains Royal Assent on $30^{\text {th }}$ March 2006 (i.e. becomes enshrined in law as an Act). This turbulent period of political conflict over the identity cards issue provides the basis from which this phase of reporting develops.

Up to this point, the reporting observes the ongoing political conflicts over the issue and includes claims originating from the discussions between political elites. In this second threshold, the amount of coverage increases noticeably (from 12 to 48 stories). Additionally, it offers a direct and negative reaction to a government Bill agreed by both Parliamentary Houses and one supported by the significant public relations activities of the then government. The focus of coverage moves from outlining the cross-party conflict to mark a newsworthy standoff between an approved Bill and one returned for amendments by the House of Lords. The newspapers mark a 'new defeat' of the Bill by the Lords at the start of March (Guardian 1 March), a further rejection of 'Blair's ID card plans' on the 7 (Telegraph 7 march) and a standoff between government and Lords ('ID card stand-off', Times 14 march). The third and fourth defeats mark the headlines of 17 and 22 (March) before the newspapers reflect on the Lords' general 'defiance' (Telegraph 29 March) and what the Guardian calls their 'lofty principles and low politics' (22 March).

Although various arguments over the proposed identity card scheme are present in this reporting, those focusing on 'technology' and 'civil liberties' appear most. Also, the analysis reveals a sea change in the stance of the newspaper stories. Emerging from the previous distanced coverage, is reporting that focuses on the sustained criticisms of the proposed identity cards scheme. Peers in the House of Lords feature now to reinforce critical claims made by previous opponents to the Bill. Reflecting this situation, the number of articles that demonstrate an 'anti' stance toward the issue double in March (second threshold) to those recorded in February (first threshold - see Figure.5). 


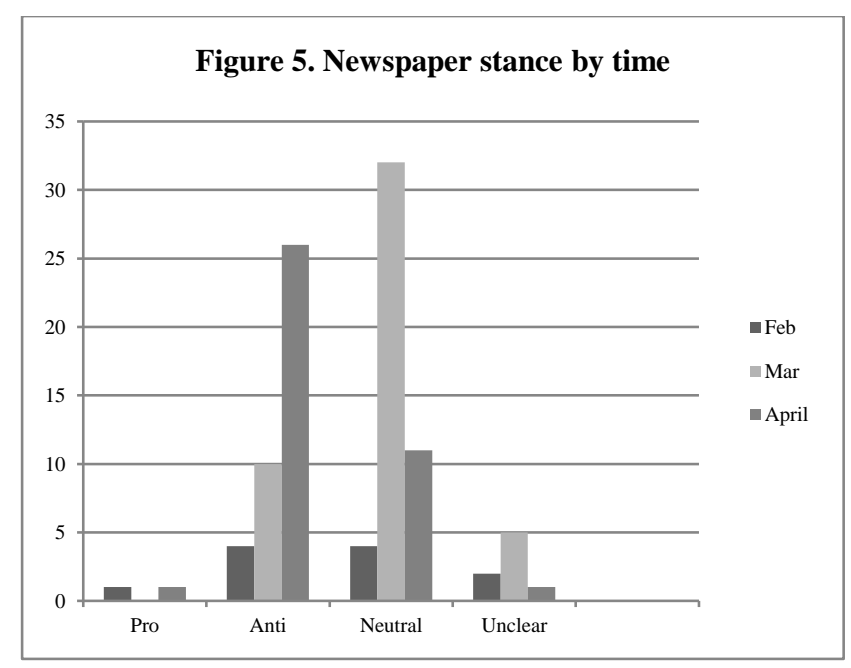

Significant also is the openness of this coverage to various voices. Stories focusing on the political conflict in the previous threshold chart the voices of senior government and senior opposition spokespeople. Thereafter in the second threshold, the pattern of the included voices and their contributions changes. Redirecting the newsworthy focus of these stories and the selection of voices important to them (i.e. to include the peers in the House of Lords) are the newfound exchanges between the House of Commons and the House of Lords. Even so, a change in the overall tone of these stories to one of sustained criticism further widens this pattern of accessed voices. Opposition MPs describe the government as on a 'headlong rush towards an 'uncosted, untested national ID database' and, in turn, 'ramming through illiberal legislation to no obvious end' (Nick Clegg, Independent $16 \mathrm{March}$, ), for example. In this threshold, we see the introduction of pressure groups who feature here to highlight the potential infringements on civil liberties from this policy in an era of the 'war on terror'. For example, Shami Chakrabarti, Director of the human rights campaign group Liberty is introduced as saying 'If this scheme is so great, people should be able to choose and vote with their feet' . Also included are academics and experts who speak with authority on the potential impacts of, or practicalities with, an identity cards system if one were introduced into the UK ( for example Simon Davis from the LSE is introduced in one headline as 'I'm the new Kelly, says ID card critic', referring to David Kelly the weapons inspector and government critic - Times 1 March) This widening of accessed voices reveals the influence of the changing political context on the reporting. An awareness of the criticism building from opposition parties and the Lords is reflected subsequently in journalists' reporting of these other voices and their concerns here. 
An analysis of the contribution that voices play offers additional evidence of the impact of the politicization process on this reporting. Most elite reporting summarises groups' or individuals' positions in news discussions and, in turn, this offers 'coverage' of --or a simple mention to (see Ericson et al 1989) -- them. Providing 'access' (ibid) for spokespeople to voice their concerns in stories is a practice that journalists perform less frequently, and one that reflects the included voices' perceived authority on the story's subject. The overview of the access and the coverage of actors involved in this developing coverage (see Figure.6) reveals two important findings: first, that senior spokespeople from the government are the most visible in the news, and in the process, they become talked about (i.e. gain coverage) in stories in a significant number within this total. Second, we observe that senior opposition figures and pressure groups gain significant amounts of opportunities to voice their concerns (i.e. gain access) despite appearing less often than government spokespeople in their overall number. In short, these insights reveal the greater use of voiced opinions (Tuchman 1972) within coverage that increasingly adopts an 'anti' stance toward the identity card issue.

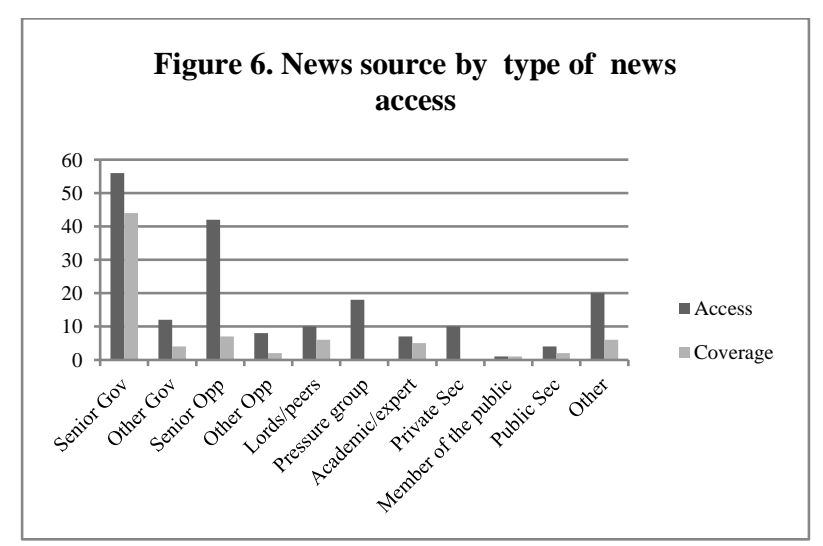

\section{Threshold 3: Initiating 'press criticism'}

On March $29^{\text {th }}$ the peers in the House of Lords and the parliamentarians reached an agreement over the Bill and therein allowed it to move forward to become legalisation (i.e. The Identity Cards Act 2006). This final threshold of reporting begins at this point and its coverage reflects the newspapers' outputs from late March to April 2006. It is noticeable that this last threshold adopts patterned coverage that is different to the previous two. The coverage in threshold three focuses on concerns of the agreed Identity Cards Bill (now Act). It discusses the possibility of the potential for reform to the legislation, raises questions over the compulsion of individuals to enter the scheme and develops upon the previous theme of civil liberties in significant 
numbers of stories (see Figure.7). There is also continuity in the position that newspapers take on the issue at this time. Focusing on the recorded stance of the news stories, we find that the majority of them are reflecting an 'anti - identity card' stance $(n=26)$. The presence of newspaper criticism complements these continuities in the content and in the stance of the articles.

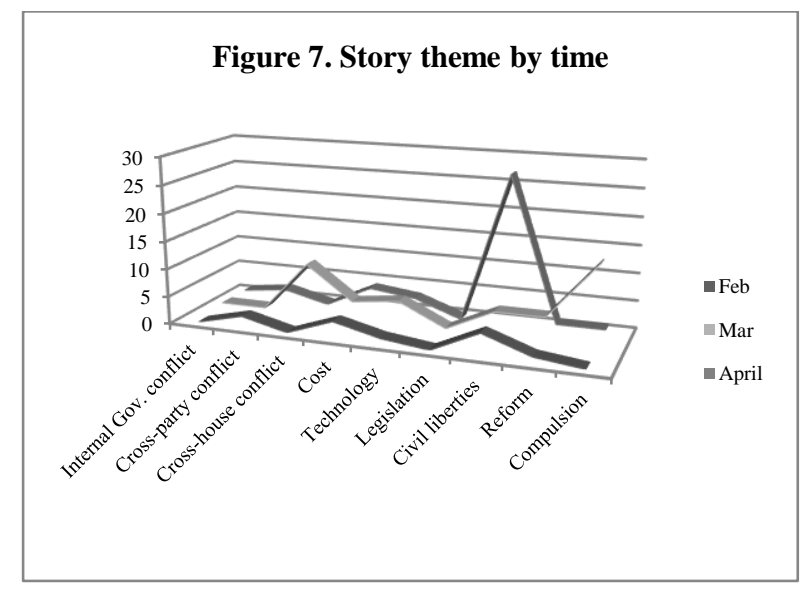

The focus of the newspaper content in threshold three develops from the staged reporting of the conflict (threshold 1) and a reporting of growing criticism toward the Bill (threshold 2). The difference between these reporting thresholds is the changing context (i.e. political conflict) that surrounds the issue. What is unusual in this new threshold is that the focus on civil liberties and negative coverage is being constructed despite an absence of explicit political conflict over the issue. Further, these stories perform critical commentaries without reference to the abundant resource of critical claims making observed earlier. Here, the newspapers react to an absence of commentary (as has been observed elsewhere - Critcher 2002; Murphy 1991) by situating themselves within the claims making process over the now agreed Bill. Their review of the arguments marks this transition point such as is illustrated by the Telegraph's comment of 'ID cards tyrannical or sensible?'. The newspapers explain the Royal Assent of the Bill as evoking a negative wartime past ('ID card laws gain Royal Assent in return to the wartime past, Telegraph $31 \mathrm{March}$ ) and even as establishing political instability ('Desperate dispatches from the banana republic of Great Britain', Times 2 April). Likewise, the main political proponents are openly criticised. The Times reflects this change in opinion by suggesting that Charles Clarke is a 'safety elephant' (23 April) and that his boast that the ID scheme would be 'very difficult' to reverse as blind to the feeling that 'are all liberals now'. Indeed, the Independent defines this new period as 'A battle for civil liberties' (24 April) and 
highlights criticism of the government's agenda (as illiberal) and the government's actions of revenge in response to those who have challenged it (e.g. 'Blair turns on critics of his 'illiberal' agenda', 25 April). Revealed from analysing the voices and judgments that are reproduced across the sampled coverage is a context that informs the newspapers' view of the issue as 'delegitimized' and one that demands the performance of press criticism (see Table 1.).

Table 1: Judgements by source by theme

\begin{tabular}{|c|c|c|c|c|c|}
\hline \multirow{2}{*}{ Theme } & \multicolumn{5}{|c|}{ Value judgements } \\
\hline & Sources only & Journalist only & $\begin{array}{c}\text { Both sources } \\
\text { and journalist }\end{array}$ & None evident & Total \\
\hline Civil Liberties & 12 & 8 & 27 & - & 47 \\
\hline Compulsion & 17 & - & 9 & 1 & 27 \\
\hline Cross-house conflict & 16 & - & 1 & 1 & 18 \\
\hline Technology & 8 & 2 & 3 & - & 13 \\
\hline Cost & 5 & - & 5 & 1 & 11 \\
\hline Cross-party conflict & 7 & 1 & - & 1 & 9 \\
\hline Reform & 4 & - & 3 & 1 & 8 \\
\hline Legislation & 2 & - & 3 & 1 & 6 \\
\hline Internal Gov. conflict & - & 1 & - & 1 & 2 \\
\hline Total & 71 & 12 & 51 & 7 & 141 \\
\hline
\end{tabular}

Significant to the coverage in this last threshold is a configuration of judgements on the issue (see Table.1). Judgments appear in the absence of voiced concerns common to the previous reported conflicts over the issue. Also, at this point, judgements on identity cards are offered by journalists and these appear in the presence or absence of supporting voices. Journalists' comments speak about identity cards and civil liberties and their overall tone is grasped by analysing them alongside the comments of other voices. For example, there is a direct contrast to observe between the focus of journalists' comments and those from senior and other government spokespeople ( $n=34$ and $n=5$, respectively). Additionally, journalists' comments match those from non-governmental spokespeople. Expressed here are positions that correspond to the negative comments made by: spokespeople of the party of opposition ( $\mathrm{n}=3$ out 4 times), representatives from the House of Lords $(n=5)$ and pressure groups $(n=4$ out of 5 times). Incidentally, there are only two articles that offer a positive ('pro') stance toward identity cards scheme at this time. 
In sum then the analysis of the reporting shows that newspaper commentary in threshold three aligns closely with those spokespeople critical of the Identity Cards Bill and, in turn, it contrasts with those of the government spokespeople who support the Bill. The positioning of the newspapers' voices corresponds neatly with the observation of the growing negative stance toward the Identity Cards Bill that builds across the reporting towards the acceptance of the Bill and thereafter in the sample. Moreover, these judgements offer a very clear 'anti- identity card' stance. One Daily Telegraph article on 27th March compares the Bill to the Nazis' 1933 'Enabling Act'. Similarly, a Times article on 29th March evokes images of George Orwell's 1984, when comparing the actions and intentions of the then present Labour government to 'Big Brother'. The architects of the Bill receive similar treatment. Charles Clark, the then Home Secretary is compared to 'a bully' (Telegraph 25 April) and together with the Prime Minister is accused of using ID cards as a part of a 'ferocious grab for power' that is 'hijacking our democracy' (Guardian 6 April). In addition, 'Not fit to be in charge' is a claim levelled at the Home Office (Times 27 April), an Observer article on 2nd April stresses the danger of the Bill for citizens' 'freedoms' and elsewhere, across the reporting, journalists reproduce the common critical repertoire voiced often by spokespeople. For example, articles describe the Bill as in terms of a previous disastrous and divisive policy 'Labour's poll tax' (Telegraph 23 April), one as an exercise in 'compulsion by stealth' that is producing a potential 'constitutional crisis' (Independent $30 \mathrm{March}$ ) and one as illustrative of 'creeping authoritarianism' that is ending liberties surreptitiously, 'by the backdoor' (Guardian 25 April).

\section{Conclusion}

This paper has introduced how a converged and critical reporting emerges in response to suggested government anti-terror legislation (i.e. an Identity Cards Bill). This performance reveals that there is more complexity to the way that the media report terrorism-related issues. It provides, on the one hand, a contrasting account, as is observed in recent thinking about 'mediatised crisis' (see Cottle 2004), to the often-expected and assumed performances characterised by the medias' limited capacity to offer a critical and a questioning approach in response to policy under these circumstances. Further, on the other, the mapped coverage provides some original insights into the changing contexts important for media performance. Charting the different 'reporting thresholds' that characterise these stories reveals the transition from which emerges this critical performance. 
Of course, we can note that some of the characteristics observed in the thresholds have appeared beforehand. For example, journalists' perception of the history of the identity card issue, as previously discussed, may well have shaped their collective reporting. Recognised as a subject of political contest and political criticism in the time before the studied coverage, the issue may have been re-reporting according to this type of 'reporting template' (Matthews 2016). Also, we see that a developing conflict between political parties and between Parliamentary Houses has informed the coverage, as has been recognised previously also. As at play, both of these factors helped to form the early disinterested and neutral reporting of the issue. But, these are less important to the reporting that followed thereafter.

Hence, the paper suggests that the sustained and developing process of negative claims making about identity cards is integral to the observed media performance. In its charting of the critical claims making, reporting shows that such an upswell was an important a catalyst for its development as was the character of the 'claims' themselves (and what features at the heart of many other studies, see Wolfsfeld 1997; Entman 2004 for example). The coverage develops to a crescendo in March on the basis of these recorded activities. An additional catalyst for this development is the providence of the issue and the evidence of political contest, which may explain its move to include journalists' adversarial criticisms of the policy (see Hallin 1986). More important to this development, however, is the discursive construction of identity cards scheme as a challenge to cultural ideas of freedom and liberty (i.e. civil liberties). Studies have suggested already that journalists will exploit ambiguous elite commentary on an issue, supplanting these with their alternative views at times (see Entman 2004). Still, less well defined in this thinking are the scenarios, like these, where the critical discussion resonates with the newspapers' perceived identity as 'a fourth estate' (i.e. acting as a protector of citizen's liberty / rights). As this paper has shown, this connection helps to galvanize an autonomous performance in response to this issue. The coverage in this last threshold includes then their independent voicing of an anti-identity card perspective.

In conclusion, this paper has demonstrated that a combination of contexts (conflict and culture) have played a role in instigating the types of autonomous reporting that voices criticism of government anti-terror legislation, despite the presence of heightened fears over further terrorism attacks in 2006. This observation asks us to reconsider our views on media performance both specifically and generally. First, we should demonstrate caution before suggesting that heightened political contexts will always determine a disempowered media and 
its uncritical reporting. Second, this caution should be extended to other occasions when it is assumed that individual circumstances will play an individual role in informing any critical media performances. Third, in addition to showing caution, we must recognise that a combination of sustained political conflict, homogeneous claims-making and the presence of particular cultural resonances can combine at times to underpin a verbally 'empowered' press performance. What is significant in this case is it did so irrespective of the heightened concerns of terrorist attacks and the subsequent mobilising of government propaganda efforts to amplify ID cards as a solution. More generally, these findings encourage us to develop a typology that maps the connections between different contexts and the subsequent media performances they inform in modern democracies. 


\section{References}

Altheide, D. L. (2006). Terrorism and the Politics of Fear. Oxford: Rowman \& Littlefield

Althaus, S. (2003). 'When news norms collide, follow the lead: New evidence for press independence', Political Communication. 20:381-414.

Barnett, B. and Reynolds, A. (2009). Terrorism and the Press: An Uneasy Relationship. London: Peter Lang

Bennett, W. L. (2011). News: The Politics of Illusion( 9th ed). New York: Longman.

Canel, M. J and Sanders, K. (2006). Morality Tales: Political Scandals and Journalism in Britain and Spain in the 1990s. New Jersey: Hampton Press

Chermak, S. (2003) 'Marketing fear: Representing terrorism after September 11', Journal for Crime, Conflict and the Media. 1 (1) 5-22

Cooke, G., Robbins, P. and Pieri, E. (2006) "“Words of mass destruction": British newspaper coverage of the genetically modified food debate, expert and non-expert reactions'. Public Understanding of Science, 15(1): 5-29

Corera, G. (2004). 'The need for complexity of foreign reporting', in D.K. Thussu and D. Freedman. (eds). War and the Media. London: Sage

Corner, J. (2007). 'Mediated politics, promotional culture and the idea of 'propaganda', Media Culture and Society. 29(4): 669-677

Cottle, S. (2004). The Racist Murder of Stephen Lawrence: Media Performance and Public Transformation. London; Preager

Cottle, S. (2006). Mediatized Conflict. Maidenhead: OU Press

Critcher,C. (2002). 'Media, government and moral panic: Paedophilla in the British press

'. Journalism Studies. 3(4): 521-535

Entman, R. (2003). 'Cascading activation: Contesting the Whitehouse's theme after 9/11', Political Communication. 20: 415-432

Entman, R. (2004). Projections of Power - Framing News, Public Opinion and US Foreign Policy. London: University of Chicago Press

Ericson, R. V., Baranek, P. M., Chan, J. B. L. (1989). Negotiating Control - A Study of News Sources. London: University of Toronto Press.

Freedman, D. (2003). 'The Daily Mirror and the war on Iraq', Mediactive. 3:95-108

Freedman, D and Thussu, D.K. (2012) Media and Terrorism: Global Perspectives. London Sage 
Hallin, D. (1986). The Uncensored War: The Media and Vietnam. London: University of California Press

Herman, E and Chomsky, N.(1988) Manufacturing Consent. Pantheon Books.

Kampfner, J. (2003). 'The Trust about Jessica' Guardian, 15 May, 2003

Lewis, S.C., and S.D. Reese. (2009). 'What is the war on terror? Framing through the eyes of journalists', Journalism \& Mass Communication Quarterly. 86(1):85-102.

McChesney, R.W. (2002) 'September 11 and the structural limitations of US journalism', in B. Zelizer and S. Allan, (eds) Journalism After September 11. London: Routledge.

Matthews, J. (2016). Media Performance in the Aftermath of Terror: Reporting Templates, Political Ritual and the UK Press Coverage of the London Bombings, 2005. Journalism Theory, Practice and Criticism 17(2):173-189

Miller, D. and Sabir, R. (2012). 'Propaganda and terrorism' in D. Freedman. and D.K. Thussu (eds). Media and Terrorism: Critical Perspectives. London: Sage

Montgomery, M. (2005) 'Talking War: How journalism responded to the events of 9/11', in S.Allan (ed.) Journalism: Critical Issues. Maidenhead: OU Press

Murphy, D. (1991). The Stalker Affair and the Press. London: Urwin

Tankard, J.W (1993). 'The empirical approach to the study of media framing', in S.D Reese., O.H Gandy and A. E. Grant. Framing Public Life: Perspectives on Media and Our Understanding of the Social World. London: Routledge

Tuchman, G. (1972). 'Objectivity as strategic ritual: An examination of newsmen's notions of objectivity’, American Journal of Sociology. 77: 660-70

Reilly, J and Miller, D. (1997) 'Scaremonger or scapegoat? The role of the media in the emergence of food as a social issue', in Caplin, P. Food, Health and Identity London: Routledge

Schudson, M. (2002). 'What's unusual about covering politics as usual', in Zelizer, B. and Allan, S. (eds), Journalism Since September 11. London: Routledge.

Thompson, J. (2000). Political Scandal: Power and Visibility in the Media Age. Cambridge: Polity Press

Tumber, H and Palmer, J. (2004) Media at War: The Iraq Crisis. London: Sage

Vliegenthart, R. and van Zoonen, L. (2011) 'Power to the frame: Bringing sociology back to frame analysis', European Journal of Communication. 26(2) 101-115

Wolfsfeld, G. (1997). Media and Political Conflict: News from the Middle East. Cambridge: Cambridge University Press 
Wolfsfeld, G. (2011). Making Sense of Media and Politics: Five Principles in Political Communication. London: Routledge

Zelizer, B. and Allan, S. (eds) Journalism After September 11. London: Routledge. 